УДК 336.14:332.1

Іщук Л.І., к.е.н., доцент

Ishchuk L. Candidate of Economic Sciences, Associate Professor https://orcid.org/0000-0002-1724-0292

Бірук Т.С., здобувач вищої освіти другого (магістерського рівня) Biruk T., applicant for higher education of the second (master's level)

\title{
ПЕРСПЕКТИВИ РОЗВИТКУ ПОТЕНЦІАЛУ МІСЦЕВИХ БЮДЖЕТІВ РЕГІОНУ
}

\section{Луиький начіональний технічний університет}

В статті досліджено фінансово-економічний потенціал місцевих бюджетів Волинської області. При цьому вказаний потенціал пропонується розкривати через конкретні запропоновані механізми, які реально застосувати на практиці.

Окреслено основні напрямки додаткового залучення коштів. Вказані напрямки вироблено на основі структурного аналізу норм Бюджетного кодексу України на предмет складу доходів місцевих бюджетів різних рівнів. При цьому систематизовано доходи, які є бюджетоутворюючими для місцевих бюджетів усіх рівнів, а тому запропоновані підходи розкриття бюджетного потенціалу, які є підходящими для усіх адміністративно-територіальних одиниць області та їх бюджетів.

Визначено основні аспекти, що впливають на збільшення дохідної бази місцевих бюджетів Волинської області та загальний розвиток регіону. До таких аспектів варто відносити сучасні політичні та глобалізаційні процеси, зокрема, місцеві вибори 2020 року, зміна місцевої влади та формування нових команд, світова фінансово-економічна криза, розповсюдження коронавірусної інфекції COVID-19 тощо.

Здійснено оцінку та розрахунок можливості залучення додаткових фінансових ресурсів до доходів місцевих бюджетів Волинської області. Що дозволило визначити прихований та реальний потенціал місцевих бюджетів, який може бути розкритий за рахунок узгодженої політики місцевої влади.

Встановлено потенціал за рахунок детінізації обігу підакцизних товарів та можливість уникнення кризових наслідків через реалізацію інфраструктурних проектів в регіоні, від чого до бюджету повертається щонайменше 17,6 \% від їх кошторису.

Результати дослідження одержані та перевірені за допомогою проведеного SWOT-аналізу, що передбачає розкриття сильних та слабких сторін місцевих бюджетів Волинської області, а також можливостей та загроз для досягнення результатів. Додатково дослідження обгрунтовано за допомогою моделі PEST, що вимагає здійснення аналізу політичних, економічних, соціальних та технологічних чинників.

Ключові слова: місиеві бюджети, доходи місиевих бюджетів, детінізація, фінансово-економічний потениіал, залучення коштів, бюджетна політика.

\section{PROSPECTS OF DEVELOPMENT OF POTENTIAL OF LOCAL BUDGETS OF THE REGION}

\section{Lutsk National Technical University}

The article examines the financial and economic potential of local budgets of Volyn region. At the same time, it is proposed to reveal this potential through specific proposed mechanisms that can be actually applied in practice.

The main directions of additional fundraising are outlined. These directions are developed on the basis of the structural analysis of norms of the Budget code of Ukraine concerning structure of incomes of local budgets of various levels. At the same time, revenues that are budget-generating for local budgets of all levels are systematized, and therefore approaches of budget potential disclosure are proposed, which are suitable for all administrative-territorial units of the region and their budgets.

The main aspects influencing the increase of the revenue base of local budgets of Volyn region and the general development of the region are determined.To such aspects should be attributed modern political and globalization processes, including the local elections of 2020, the change of local government and the formation of new teams, the global financial and economic crisis, the spread of coronavirus infection COVID-19 etc.

The assessment and calculation of the possibility of attracting additional financial resources to the revenues of local budgets of Volyn region was carried out. This calculation identified the hidden and real potential of local budgets, which can be revealed through a coordinated policy of local authorities. 
The potential at the expense of de-shadowing the circulation of excisable goods and the possibility of avoiding crisis consequences through the implementation of infrastructure projects in the region has been established, from what at least $17.6 \%$ of their estimate is returned to the budget.

The research results were obtained and verified with the help of the SWOT-analysis, which provides for the disclosure of strengths and weaknesses of local budgets of Volyn region, as well as opportunities and threats to achieve results. The study is further substantiated by the PEST model, which requires an analysis of political, economic, social and technological factors.

Key words: local budgets, revenues of local budgets, de-shadowing, financial and economic potential, fundraising, budget policy.

Постановка проблеми у загальному вигляді i iї зв'язок 3 важливими науковими та практичними завданнями. 2020 рік передбачає існування ряду викликів та загроз для місцевих бюджетів. Крім того, проведення місцевих виборів завершує реформу децентралізації, в рамках якої місцева влада отримує не лише повний інструментарій управління територією, а й новий адміністративний поділ та команду. Разом $з$ тим, такі процеси супроводжуються кризовими явищами, які стануть певним випробуванням для нової влади. Ефективність влади на місцях у повній мірі залежатиме від результатів виходу із кризи та рівня зростання бюджету й розвитку території.

Економічне зростання території не має залежати виключно від використання бюджетних коштів, у розмірах, що надходять. Місцева влада повинна застосовувати прогресивні методи управління щодо оптимізації видаткової частини, реалізації контрольно-наглядових повноважень та пошук нових шляхів залучення коштів до бюджетів. Волинська область не є винятком, а тому на неї розповсюджуються усі вищевказані тези. Поряд з цим, область має ряд виняткових переваг, які необхідно імплементувати в практичній площині для створення сталого економічного зростання регіону.

Про прогресивність та фінансове благополуччя регіону, а відповідно й дієвість місцевої влади також свідчить рівень забезпечення та добробуту проживаючого в області населення. Це пов'язано з тим, що саме його діяльність рівень доходів, зайнятості забезпечують формування дохідної частини бюджету незалежно від рівня локалізації.

Аналіз останніх досліджень, у яких започатковано вирішення проблеми. Місцеві бюджети перебувають в активному полі наукових досліджень протягом останніх років. Так чи інакше, вони викликали реальний науковий інтерес через практичну обумовленість та перебуванням реформи децентралізації на порядку денному політичних реалій держави.

Дослідженням цього питання займалися такі вчені як: О.Д. Василик, Ю. Ганущак, В.В. Зубріліна, А. Колодій, М.І. Кульчицький, Г. Лопушняк, О.В. Нєізвєстна, К.В. Павлюк, Ю. Пасічник, Ю.О. Раделицький, К. Ровинська, М.В. Тарасюк та ін. Поряд зі значною кількістю наукових досліджень, питання актуальності обраної теми обумовлюється великою кількістю законодавчих та організаційних змін, які потребують здійснення їх доктринального аналізу та обгрунтування.

Цілі статті. Метою статті $є$ проведення комплексного дослідження усіх ланок місцевих бюджетів Волинської області, незалежно від локалізації, визначення їх ролі та значення, а також формування пропозицій щодо оптимізації та збільшення дохідної частини місцевих бюджетів щодо економічного зростання регіону та підвищення рівня життя місцевого населення.

Виклад основного матеріалу дослідження 3 повним обгрунтуванням отриманих наукових результатів. Функціонування бюджетної системи Волинської області слугує певним важелем перерозподілу фінансових ресурсів, з метою направлення їх на конкретні сфери, фінансуючи таким чином видатки. За рахунок цього функціонує комунальна складова, а також здійснюються заходи щодо покращення життя регіону та його фінансово-економічного зростання. 
При цьому важливе місце займають фактори наявності значного кола повноважень місцевої влади для розвитку регіону, а також наявності фінансових ресурсів. Започаткована у 2014 році реформа децентралізації лише заклала початки проведення глобальної реформи на місцях. Однак, здійснивши первинний перерозподіл коштів між бюджетами, реформа дещо зупинилася. Разом з тим, 17.07.2020 року Верховна Рада України прийняла Постанову «Про утворення та ліквідацію районів», а в подальшому - проведено місцеві вибори по усіх напрямках та в рамках країни. Таким чином, це можна назвати завершальним етапом реформи децентралізації та переведення iii 3 теоретичної у практичну площину, де питання життєдіяльності та благополуччя регіону залежатиме лише від місцевої влади, яка обирається з урахуванням сучасних викликів та реалій, отримуючи при цьому значний як фінансовий, так і бюрократичний інструментарій.

Щодо Волинської області, то вказаною вище Постановою кількість районів 3 початку 2021 року скорочується з 16 до 4, а саме: Володимир-Волинський район, КаміньКаширський район, Ковельський район, Луцький район. Отже, місцеві бюджети Волинської області знаходяться на рубежі значних викликів та практичних перетворень, що стосуються внутрішнього функціонування. У зв'язку з цим варто проаналізувати основні сильні та слабкі сторони, виклики, загрози та можливості, з якими Волинська область існуватиме 32021 року. Здійснювати таке дослідження прийнято із використанням методів та інструментарію SWOT-аналізу.

SWOT-аналіз має за мету отримати чітке бачення розвитку (в нашому випадку бюджетів області) шляхом узагальнення та систематизації інформації про сильні та слабкі сторони регіону, а також про потенційні можливості та загрози. За допомогою інструментарію SWOT-аналізу проведемо оцінку сучасного стану та реальних можливостей розвитку бюджетів Волинської області.

Сильні сторони бюджетів Волинської області:

- проведення місцевих виборів на усіх рівнях, що як наслідок має формування нових команд, що бажають здійснювати реформи на місцях;

- наявність нових програм розвитку новообраної місцевої влади; бюджетів;

- укрупнення районного поділу, що як наслідок має збільшення розміру

- наявність власних доходів місцевих бюджетів;

- завершення реформи децентралізації; Білорусією;

- розвиток конкуренції за рахунок спільних кордонів з Свропейським Союзом та

- наявність реальної можливості створення нових робочих місць;

- можливість застосовувати інноваційні моделі місцевого управління та самоврядування;

Слабкі сторони:

- постійні зміни законодавства, зокрема в податковій сфері;

- негативний вплив карантинних обмежень внаслідок коронавірусної інфекції COVID-19.

- високий рівень корупційних ризиків та ситуацій конфлікту інтересів посадових осіб;

- залежність регіону від центральної влади внаслідок значного обсягу міжбюджетних трансфертів в структурі бюджетів;

- збереження залежності місцевої влади в прийнятті складних та глобальних рішень;

- низький рівень партнерства місцевої влади з представниками бізнесу; 
підприємств;

- проблеми матеріально-технічного забезпечення комунальних установ та

- кадрові проблеми;

- складність процесу залучення кредитів під місцеві гарантії;

Можливості:

- створення спеціальних податкових режимів для окремих сфер;

- вдосконалення та спрощення регуляторної та дозвільної політики держави;

- залучення інвестицій;

- запровадження інноваційної діяльності в регіоні;

- взаємодія та співпраця у спільних проектах із більш прогресивними регіонами

(в тому числі і закордонними);

- зміна податкового законодавства для утворення незалежних місцевих бюджетів;

- залучення нових методів та інструментів управління бюджетною сферою регіону;

- громадська участь і контроль в освоєнні місцевих бюджетів;

- ефективне використання людського потенціалу;

- створення високого рівня довіри до місцевої влади.

Аналіз загроз фінансової безпеки Волинської області та ії бюджетам здійснено в таблиці 1, шляхом поділу їх на мікроекономічна та макроекономічні.

Таблиця 1 - Загрози фінансової безпеки регіонів

\begin{tabular}{|c|c|}
\hline Макроекономічні & економічні \\
\hline $\begin{array}{l}\text { - збереження тенденції високого рівня } \\
\text { безробіття; } \\
\text { - високий рівень інфляції та нестабільності } \\
\text { національної валюти; } \\
\text { - збереження високого рівня тіньової економіки; } \\
\text { - неефективність проведеної реформи } \\
\text { децентралізації; } \\
\text { - зменшення податкового потенціалу регіону; } \\
\text { - зменшення кількості економічно активного } \\
\text { населення; } \\
\text { - несприятлива фінансово-кредитна політика та } \\
\text { ситуація; } \\
\text { - ризик тотального локдауну внаслідок } \\
\text { збільшення кількості захворюваності СОVID-19; } \\
\text { - неефективність контрольно-наглядових } \\
\text { повноважень щодо використання бюджетів. }\end{array}$ & $\begin{array}{l}\text { - збільшення кількості неплатників податків що є } \\
\text { наслідком податкові заборгованості перед } \\
\text { бюджетом; } \\
\text { - низький рівень конкурентоспроможності товарів } \\
\text { та послуг, що вироблені (надані) в регіоні; } \\
\text { - неефективна кадрова політика щодо осіб, } \\
\text { відповідальних за бюджетний процес; } \\
\text { - низький рівень місцевих інвестицій; } \\
\text { - перевага обсягу сировинної економіки над } \\
\text { переробною; } \\
\text { - низьке стимулювання місцевої влади щодо } \\
\text { залучення додаткових коштів до бюджетів; } \\
\text { - зростання рівня амортизації основних фондів } \\
\text { місцевих підприємств; } \\
\text { - неефективне використання податкового } \\
\text { потенціалу регіону; } \\
\text { - зростання рівня злочинності. }\end{array}$ \\
\hline
\end{tabular}

Крім того, SWOT-аналіз можливо проводити, використовуючи не абстрактні, а універсальні моделі. Наприклад, в моделі PEST використовується не докладні набори чинників, а 4 великі категорії, що є загальним обрисом для конкретних факторів впливу:

- політичні чинники;

- економічні чинники;

- соціальні чинники;

- технологічні чинники.

Тож розглянемо особливості впливу кожної групи чинників на місцеві бюджети Волинської області.

1. Політичні чинники:

- місцеві вибори можуть призвести до виникнення короткотривалого застою, внаслідок перерозподілу повноважень та ознайомлення із специфікою діяльності нової команди; 
- державне регулювання на місцях сприятиме зниженню авторитету місцевої влади, а тому й iii ефективності;

- постійні законодавчі зміни нівелюють діяльність на місцях, породжуючи неможливість побудови довготривалих стратегічних планів;

- збереження тенденції бюрократизації зменшуватиме ефективність використання бюджетних ресурсів;

- надмірний контроль центральних органів виконавчої влади може створити ситуацію тінізації доходів населення.

2. Економічні чинники:

- валовий регіональний продукт є прямим фактором впливу на обсяг доходів бюджетів області;

- динаміка офіційного курсу гривні безпосередньо впливає на обсяг прибутку експортонаправлених підприємств регіону, що в свою чергу входить до місцевих бюджетів;

- зайнятість населення здійснює подвійний вплив на місцеві бюджети: залежить обсяг доходів бюджету із податку на доходи фізичних осіб; залежить обсяг видатків щодо допомоги по безробіттю;

- заміна імпортними товарами місцевих негативно впливає на обсяг доходів місцевих бюджетів;

- легалізація тіньових потоків збільшує дохідну базу місцевих бюджетів;

- розкриття економічних можливостей регіону забезпечує фінансове наповнення місцевих бюджетів.

3. Соціальні чинники:

- демографічні зміни внаслідок відтоку кадрів закордон зменшує податкові надходження місцевих бюджетів;

- базові цінності місцевого населення формують структуру бюджету регіону;

- рівень життя населення характеризує рівень успішності місцевої влади у використанні бюджетів.

4. Технологічні чинники:

- створення якісно нових продуктів в регіоні значно впливає на збільшення дохідної частини місцевих бюджетів;

- розвиток та залучення новітніх технологій сприяє спрощенню різних процесів, що як наслідок допомагає вирішити інші проблемні питання життя регіону;

- якісне технологічне оснащення місцевих підприємств робить продукцію конкурентоспроможною з аналогами (в тому числі й іноземними).

Завершення здійснення SWOT-аналізу має супроводжуватися побудовою стратегії розвитку досліджуваного об'єкта на основі аналізу факторів.

Прогресивним вбачається використання так званого парного методу, що полягає в поєднанні пар факторів:

- метод Maxi-Maxi, що полягає у використанні сильних сторін для реалізації певних можливостей;

- метод Mini-Maxi, що полягає у використанні можливостей для знищення слабких сторін;

- метод Maxi-Mini, що полягає у використанні сильних сторін для зниження негативного впливу загроз;

- метод Mini-Mini, що полягає в аналізі взаємодії слабких сторін і загроз (стратегія мінімізації втрат).

Вбачаємо найбільш раціональним, з урахуванням сучасних реалій, дослідити шляхи збільшення дохідної частини місцевих бюджетів Волинської області за допомогою методу Maxi-Mini. Це пов'язано з тим, що загрози, які існують, вони є цілком 
реальними та невідворотними, а тому єдиним правильним шляхом діяльності місцевої влади має стати випередження їх негативних наслідків.

Розкриття потенціалу місцевих бюджетів Волинської області слід досліджувати крізь призму світової фінансової кризи, перебування економіки України в рецесії, наявності реальної загрози тотального локдауну та закриття кордонів через розповсюдження коронавірусної інфекції. Вищезазначені загрози відкидають глобальне збільшення фінансової стабільності регіону за рахунок інвестицій, а тому розглянемо можливості, які на наше переконання, є реальними в практичній реалізації.

Якщо проаналізувати Бюджетний кодекс України на предмет доходів, що $є$ бюджетоутворюючими, то основними, які є значними та перспективними є:

1. У бюджетах сіл, селищ та міст:

- 60 \% податку на доходи фізичних осіб, що сплачується на їх території;

- $100 \%$ рентної плати за видобування корисних копалин місцевого значення;

- 100 \% податку на прибуток підприємств комунальної власності;

- 100 \% акцизного податку з реалізації суб'єктами господарювання роздрібної торгівлі підакцизних товарів.

2. У обласному бюджеті:

- 15 \% податку на доходи фізичних осіб, що сплачується на їх території;

- 10 \% податку на прибуток підприємств;

- 100 \% податку на прибуток підприємств комунальної власності засновником яких є обласна рада;

- 25 \% рентної плати за видобування корисних копалин загальнодержавного значення.

3. У районному бюджеті:

- 100 \% податку на прибуток підприємств комунальної власності засновником яких є районна рада.

Відповідно до статистичних даних головного управління статистики у Волинській області, станом на кінець 2019 року у Волинській області зареєстровано 7900 безробітних. Враховуючи загальне скорочення виробництва, зменшення рівня виконання бюджетів та кризові явища, використаємо вищезазначений потенціал та законні можливості за допомогою запропонованого комплексного підходу збільшення та оптимізації дохідної частини місцевих бюджетів.

На наше переконання, вихід із рецесії та економічної кризи можливий шляхом реалізації суспільно необхідних інфраструктурних проектів області. Перевагами цього можуть слугувати наступні твердження:

- територія здійснює оновлення власної інфраструктури;

- інфраструктурні проекти паралельно забезпечують існування та зростання великих сфер: виробництво, будівництво, проектні сфери тощо.

- значна частина коштів в подальшому повертається у бюджет.

- зменшується кількість безробітних за рахунок нарощення кількості робочих місць, які задіються в інфраструктурних проектах.

Розглянемо зазначене на конкретних розрахунках. Якщо розглядати усі бюджети на місцях як єдине ціле, то бюджетоутворюючими доходами є:

- $75 \%(60 \%+15 \%)$ податку на доходи фізичних осіб, що сплачується на території Волинської області;

- 100 \% рентної плати за видобування корисних копалин місцевого значення.

- 100 \% податку на прибуток підприємств комунальної власності; значення;

- 25 \% рентної плати за видобування корисних копалин загальнодержавного

- 10 \% податку на прибуток підприємств. 
Створимо уявну модель виділення 1000000 грн. бюджетних коштів на інфраструктурні проєкти Волинської області та дослідимо розмір коштів, які в подальшому повертаються до бюджетів.

Аналіз одиничних проєктів в рамках президентської програми «Велике будівництво» дає змогу визначити, що кожен інфраструктурний проект у кошторисі витрат передбачає: копалини);

- 75 \% витрат на матеріальні ресурси (з них 60 \% на асфальтобетон та корисні

- 10 \% витрати на заробітну плату;

$-1 \%$ прибутку;

- 14 \% інших витрат (в основному документарні).

При цьому витрати матеріальних ресурсів орієнтовно складаються на $50 \% 3$ щебню та 40 \% 3 піску, які є корисними копалинами місцевого значення.

Якщо запозичити такий же ж кошторис у нашу уявну модель, то отримаємо наступні абсолютні цифри у загальній структурі:

- 750000 грн. витрат на матеріальні ресурси (з них 600000 на асфальтобетон) ;

- 100000 грн. витрати на заробітну плату;

- 10000 грн. прибутку;

- 14000 грн. інших витрат (в основному документарні).

Вартість використаного щебню та піску становитиме:

$600000 \times(50 \%+40 \%=90 \%)=540000$ грн.

При цьому, до місцевих бюджетів Волинської області в якості податків щонайменше надійде:

1. 100000 грн. х $18 \%$ (ставка ПДФО) $=18000$ грн.

2. 10000 грн. х $10 \%$ (відсоток відрахування до місцевих бюджетів з податку на прибуток) $=1000$ грн.

3. Відповідно до Податкового кодексу, розрахунок рентної плати виглядає наступним чином:

$$
\text { Пзн }=\text { Vф х Вкк х Свнз х Кпп, }
$$

де Vф - обсяг видобутої корисної копалини;

Вкк - її вартість;

Свнз - ставка рентної плати;

Кпп - коригуючий коефіцієнт.

Ставка рентної плати 3 покладів, що залягають на глибині до 5000 метрів (розповсюджується і на пісок і на щебінь) складає $29 \%$ його вартості.

Таким чином, зобов'язання з рентної плати становитиме:

Пзн $=$ Vф х Вкк (складає 540000 грн.) х $29 \%=156600$ грн.

Таким чином, загальна сума надходжень до місцевих бюджетів Волинської області в рамках кейсу становить:

18000 грн. +1000 грн. +156600 грн. $=175600$ грн.,

що в загальній структурі складає 17,6 \% від бюджету кейсу. Крім того, варто взяти до уваги, що наш розрахунок не враховує надходження до місцевих бюджетів Волинської області від супутніх галузей, які також отримують доходи, а їх працівники заробітні плати від реалізації загального інфраструктурного проекту.

Таким чином, можемо зазначити, що якщо місцева влада ініціює інфраструктурний проєкт, то вона може гарантовано розраховувати на повернення щонайменше 17,6 \% від його кошторису у вигляді доходів місцевих бюджетів. Поряд 3 цим, варто наголосити, що такий результат є можливим лише у випадку виконання норм законів, детінізації усіх процесів та сплати податків у повному обсязі. 
Крім того, можливим є використання в рамках таких інфраструктурних проектів праці зареєстрованих безробітних. Як зазначалося вище, на території Волинської області їх число складає 7900 осіб. Використавши потенціал праці безробітних та встановивши їм оклад у розмірі мінімальної заробітної плати, річний податковий потенціал із податку на доходи фізичних осіб становитиме:

7900 х 5000 грн. х $18 \% 12=85320000$ грн.

Таким чином, потенціал зарахування коштів у вигляді податку на доходи фізичних осіб до місцевих бюджетів Волинської області становитиме:

$85320000 \times 75 \%=63,99$ млн. грн.

У випадку встановлення заробітної плати у розмірі, що перевищує мінімальний, податковий потенціал з податку на доходи фізичних осіб, що можуть отримати місцеві бюджети Волинської області відповідно зросте.

Із вищевказаного можна зробити висновок про наявність реального потенціалу місцевих бюджетів Волинської області оптимізації видаткової частини 3 метою збереження надходжень дохідної частини на рівні не нижче попередніх періодів, 3 урахуванням загальносвітових кризових явищ. Разом 3 тим, вихід 3 кризи $є$ можливим лише у випадку зваженої та узгодженої бюджетної політики місцевої влади.

Крім вищезазначеного вбачаємо наявність реального потенціалу місцевих бюджетів збільшити дохідну частину за рахунок акцизного податку. При цьому розглянемо потенціал доходів місцевих бюджетів від легалізації продажу таких підакцизних товарів як тютюнові вироби, пальне та алкогольні вироби.

Компанія Kantar TNS в Україні яка є одним із світових лідерів маркетингових досліджень визначила, що за період 2016-2019 років тіньовий тютюновий ринок збільшився у 7 разів: 3 1,1 \% до 7,5 \% від легального ринку, досягнувши показника 3,8 млрд шт. сигарет [4, с. 21]. Тобто орієнтовний показник тіньового обігу сигарет у Волинській області, (з урахуванням кількості проживаючого населення в області 1,031 мільйона осіб та Україні - 37 мільйонів осіб) становить:

3,8 млрд шт. / 37 млн. ос. х 1,031 млн. ос. = 105,9 млн. шт. (5,295 млн. пачок).

Відповідно до статті 215 Податкового кодексу, акцизний податок за сигарети становить 12 \% від їх вартості. Середня вартість пачки цигарок складає 40 грн. Таким чином, сума акцизного податку, що не надходить до місцевих бюджетів Волинської області внаслідок тіньового обігу складає:

5,295 млн. пачок х 40 грн. х 12\%=25,416 млн. грн.

Щодо пального, то відповідно до відомостей Нафтогазової асоціації України, за 2018 рік в рамках держави було продано близько 1,2 млн. тон пального поза автозаправних станцій. Згідно з їх дослідженням, в «тіні» знаходиться в середньому $40 \%$ роздрібного ринку. Відповідно до прогнозу Асоціації у 2019 році тіньовий обіг пального складе 1,5 млн. тон (2,06 млн. літрів) [5]. Тобто орієнтовний показник тіньового обігу пального у Волинській області, (з урахуванням кількості проживаючого населення в області 1,031 мільйона осіб та Україні - 37 мільйонів осіб) становить:

2,06 млн. л. / 37 млн. ос. х 1,031 млн. ос. $=57401$ л.

Відповідно до статті 215 Податкового кодексу, акцизний податок за пальне для транспортних засобів становить 213,5 євро за 1000 літрів. Таким чином, сума акцизного податку, що не надходить до місцевих бюджетів Волинської області внаслідок тіньового обігу пального складає:

57401 л. / 1000 л. х 213,5 євро = 12255,11 євро (орієнтовно 0,417 млн. грн.)

Також дослідимо потенціал акцизного податку 3 алкоголю. Відповідно до досліджень компанії «Сучасні маркетингові дослідження» (проєкт «Рейтинг», що підтримується Державною податковою службою України) кожен українець споживає 8,6 літрів чистого алкоголю на одну людину на рік. При цьому рівень тіньового 
алкогольного ринку сягає $45 \%$ або 3,9 літри на особу [6]. Таким чином, орієнтовний показник тіньового обігу алкоголю у Волинській області, (з урахуванням кількості проживаючого населення в області 1,031 мільйона осіб) становить:

3,9 л. х 1,031 осіб $=4,02$ млн. л.

Крім того, вищевказана компанія встановила, що структура споживання алкоголю в Україні виглядає наступним чином:міцний алкоголь (вміст спирту 40 \%) - 52 \%; вино $5 \%$;пиво - $42 \%$;інше - $1 \%$.

Якщо запозичити вказану структуру споживання на Волинську область, то вона виглядатиме наступним чином:міцний алкоголь (вміст спирту $40 \%$ - 2,09 млн. л.;вино - 0,201 млн. л.;пиво - 1,69 млн. л.;інше 0,04 млн. л.

Відповідно до статті 215 Податкового кодексу, мінімальний акцизний податок за обіг вказаних вище алкогольних напоїв становить: міцний алкоголь - 126,96 грн. за 1 л. 100 \% спирту; вино - 0,01 грн. за 1 л.; пиво - 2,78 грн. за 1 л.

Таким чином, сума акцизного податку, що не надходить до місцевих бюджетів Волинської області внаслідок тіньового обігу алкоголю складає:

2,09 млн. л. х 0,4 (відсоток вмісту спирту) х 126,96 + 0,201 млн. л. х 0,01 грн. + 1,69 млн. л. х 2,78 грн. $=106,14$ млн. грн. + 0,00201 млн. грн. $+4,6982$ млн. грн. $=$ 110,84021 млн. грн.

На підставі проведених розрахунків, можливо встановити, що фактичне ненадходження акцизного податку до місцевих бюджетів Волинської області внаслідок існування тіньового ринку підакцизних товарів трьох груп товарів становить:

25,416 млн. грн. + 0,417 млн. грн. $+110,84021$ млн. грн. $=136,67321$ млн. грн.

Залучення вказаних вище коштів до місцевих бюджетів на розвиток Волинської області є можливим лише у випадку активної боротьби та реалізації заходів запобігання розвитку тіньових ринків підакцизних товарів. При цьому, така боротьба в більшій мірі залежить від політичної волі держави та діяльності правоохоронних органів, Державної митної та податкових служб. В свою чергу розвиток тіньових процесів у даній сфері відбувається через постійні прагнення дотримання Директив ЄС щодо акцизного оподаткування шляхом збільшення ставок акцизного податку.

Отже, вищенаведене свідчить про існування реальних можливостей збільшення дохідної частини місцевих бюджетів Волинської області по різних напрямках управління. При цьому, спостерігатимемо реалізацію конкретних кроків новообраною місцевою владою із оптимізації бюджетної політики та бюджетного процесу* .

*Апробація матеріалів дослідження [1].

\section{Список бібліографічного опису}

1. Бірук Т.С. Формування та виконання місцевих бюджетів за доходами: проблемні аспекти та перспективи розвитку (на матеріалах бюджету Волинської області): кваліфікаційна робота здобувача другого (магістерського) рівня вищої освіти спеціальності 072 Фінанси, банківська справа та страхування освітньо-професійної програми «Фінанси, банківська справа та страхування». Луцький національний технічний університет. Луцьк, 2020.

2. Ніколаєва А.М., Іщук Л.І. Ефективне використання бюджетних коштів у системі соціально-економічного розвитку регіонів. Економічний форум. Наук. ж-л. 2018. №4. С. 116-121.

3. Департамент фінансів Волинської обласної державної адміністрації. Офіційний веб-сайт URL: http://www.finance.voladm.gov.ua/articles/id-493/ (дата звернення: 20.09.2020).

4. Новицька Н.В., Хлєбнікова І.І., Коротун В.І., Кощук Т.В. Модернізація системи контролю за обігом тютюнових виробів / за заг. ред. Новицької Н.В. Ірпінь. Хмельницький, 2020. 120 с.

5. Як працює нелегальний ринок нафтопродуктів в Україні URL: https://mind.ua/publications/20194305-yak-pracyuenelegalnij-rinok-naftoproduktiv-v-ukrayini/ (дата звернення: 10.11.2020).

6. Субочев О. Ринок алкогольної продукції URL: https://rating.zone/rynok-alkoholnoi-produktsii/ (дата звернення: 10.11.2020).

\section{References:}

1. Biruk T.S. Formuvannia ta vykonannia mistsevykh biudzhetiv za dokhodamy: problemni aspekty ta perspektyvy rozvytku (na materialakh biudzhetu Volynskoi oblasti): kvalifikatsiina robota zdobuvacha druhoho (mahisterskoho) rivnia vyshchoi 
osvity spetsialnosti 072 Finansy, bankivska sprava ta strakhuvannia osvitno-profesiinoi prohramy «Finansy, bankivska sprava ta strakhuvannia». Lutskyi natsionalnyi tekhnichnyi universytet. Lutsk, 2020.

2. Nikolaieva A.M., Ishchuk L.I. Efektyvne vykorystannia biudzhetnykh koshtiv u systemi sotsialno-ekonomichnoho rozvytku rehioniv. Ekonomichnyi forum. Nauk. zh-1. 2018. №4. S. 116-121.

3. Departament finansiv Volynskoi oblasnoi derzhavnoi administratsii. Ofitsiinyiveb-sait URL: http://www.finance.voladm.gov.ua/articles/id-493/ (data zvernennia: 20.09.2020).

4. Novytska N.V., Khliebnikova I.I., Korotun V.I., Koshchuk T.V. Modernizatsiia systemy kontroliu za obihom tiutiunovykh vyrobiv / zazah. red. Novytskoi N.V. Irpin. Khmelnytskyi, 2020. $120 \mathrm{~s}$.

5. Yak pratsiuie nelehalnyi rynok naftoproduktiv v Ukraini URL: https://mind.ua/publications/20194305-yak-pracyuenelegalnij-rinok-naftoproduktiv-v-ukrayini/ (data zvernennia: 10.11.2020).

6. Subochev O. Rynok alkoholnoi produktsii URL: https://rating.zone/rynok-alkoholnoi-produktsii/ (data zvernennia: 10.11.2020).

Дата подання публікації 13.12.2020 р.

УДК 332.133:339.3

Ковальська Л.Л., д.е.н., проф., завідувач кафедри підприємництва, торгівлі та біржової діяльності

D.Sc. (Economics), Professor, Head of Department, Professor of the Department of Entrepreneurship, Trade and Exchange Activities, https://orcid.org/0000-0003-2924-9857

Голодюк Г.І., к.т.н., доцент кафедри товарознавства та експертизи в митній справі Galina Golodyuk, Docent Department of Commodity Science and Expertise in Customs https://orcid.org/0000-0002-9740-5498 Кривов'язюк Б.І. Kryvovyazyuk B.

\title{
АНАЛІТИЧНЕ ДОСЛІДЖЕННЯ РОЗВИТКУ ПІДПРИЕМНИЦТВА РЕГІОНІВ ДЕРЖАВИ У СФЕРІ ТОРГІВЛІ
}

\author{
Луцький наиіональний технічний університет
}

У статті проведено аналітичне дослідження розвитку підприємництва в сфері торгівлі. Проаналізовано передумови забезпечення розвитку підприємництва в сфері торгівлі. Зокрема, такі показники як кількість підприємств за видами економічної діяльності; кількість підприємств, які здійснювали діяльність із роздрібної торгівлі за видами економічної діяльності; кількість об'єктів торгівлі (загалом, у містах та селищах міського типу, у сільській місцевості); торгова мережа об'єктів роздрібної торгівлі (в розрізі магазинів, аптек та автозаправних станцій); забезпеченість об'єктами роздрібної торгівлі (всього, магазинами, торговою площею). Здійснено аналіз результатів розвитку підприємництва в сфері торгівлі. У даному напрямів проаналізовано такі показники як оборот роздрібної торгівлі; роздрібний товарооборот підприємств роздрібної торгівлі за видами економічної діяльності; індекси фізичного обсягу роздрібного товарообороту підприємств роздрібної торгівлі. Проведено комплексну оцінку розвитку підприємництва регіонів держави в сфері торгівлі. Здійснено групування регіонів держави за рівнем передумов, результатів та розвитку підприємництва в сфері торгівлі. Аналітичні дослідження показали, що найвищий рівень розвитку підприємництва у сфері торгівлі спостерігається у м. Києві. До групи регіонів із середнім рівнем розвитку підприємництва в сфері торгівлі віднесено Донецьку, Київську, Львівську, Одеську, Харківську області. Такі регіони держави як Вінницька, Волинська, Дніпропетровська, Житомирська, Закарпатська, Запорізька, Івано-Франківська, Кіровоградська, Луганська, Миколаївська, Полтавська, Рівненська, Сумська, Херсонська, Хмельницька, Черкаська, Чернівецька, Чернігівська області потрапили до групи із низьким рівнем розвитку підприємництва в сфері торгівлі. Узагальнено висновки, що спостерігається група регіонів, які володіють потенційними 